\title{
Use of Chemicals to Realize the Productivity Potential in Pomegranate through Increased Flowering and Fruiting
}

\author{
S. Firoz Hussain ${ }^{1 *}$, P. Sampath Kumar ${ }^{1}$, B.N.S. Murthy ${ }^{2}$, K.K. Upreti ${ }^{4}$, \\ M.L.N. Reddy ${ }^{3}$, J. Satisha ${ }^{1}$ and R.H. Laxman ${ }^{4}$ \\ ${ }^{1}$ Division of Fruit Crops, ICAR - IIHR, Hesaraghatta, Bengaluru, Karnataka, India \\ ${ }^{2}$ Horticulture Commissioner, Government of India, India \\ ${ }^{3}$ Dr YSRHU, Venkataramannagudem, A.P., India \\ ${ }^{4}$ Division of Plant Physiology and Bio Chemistry, ICAR - IIHR, Hesaraghatta, \\ Bengaluru, Karnataka, India \\ *Corresponding author
}

\begin{tabular}{|c|c|}
\hline & $\mathbf{A} B \mathbf{S} \mathbf{T} \mathbf{A} \mathbf{C}$ \\
\hline & \multirow{7}{*}{ 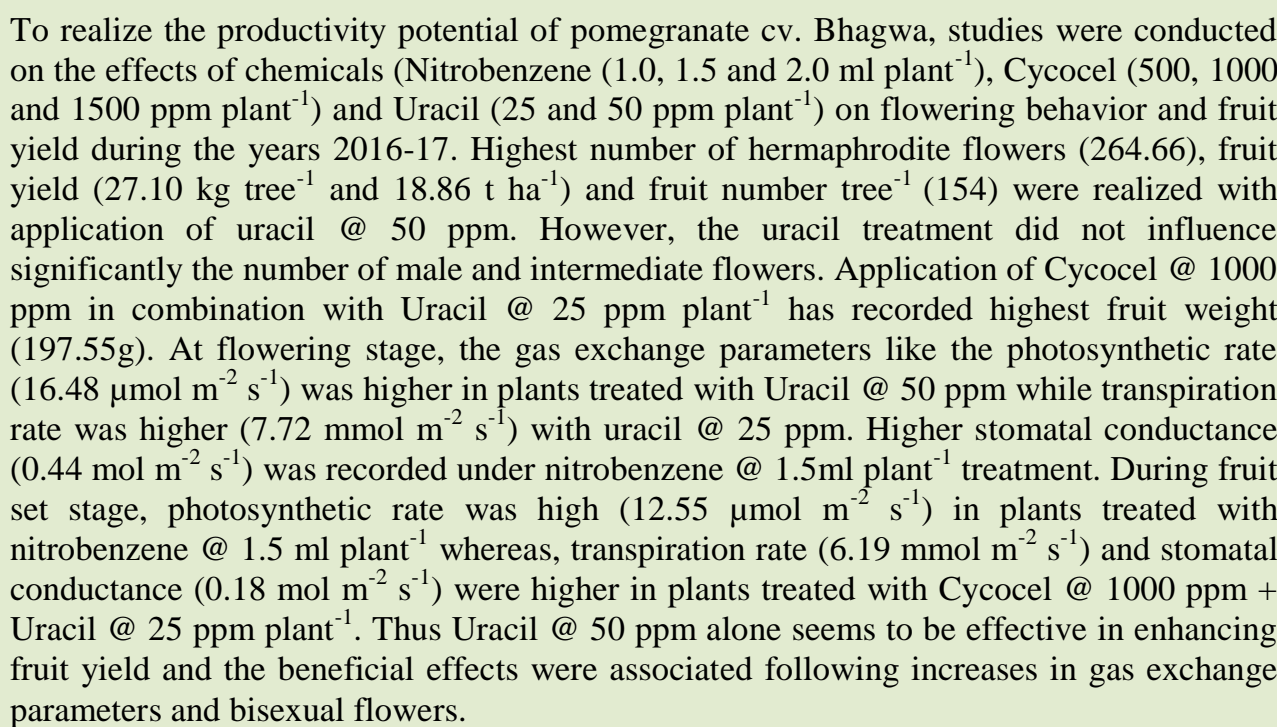 } \\
\hline Keywords & \\
\hline $\begin{array}{l}\text { Pomegranate, Gas } \\
\text { exchange } \\
\text { parameters, }\end{array}$ & \\
\hline $\begin{array}{l}\text { Flowering and Fruit } \\
\text { yield. }\end{array}$ & \\
\hline Article Info & \\
\hline $\begin{array}{l}\text { Accepted: } \\
17 \text { September } 2017 \\
\text { Available Online: } \\
10 \text { October } 2017\end{array}$ & \\
\hline & \\
\hline
\end{tabular}

\section{Introduction}

Pomegranate (Punica granatum L.) is nutritionally an important commercial fruit crop of arid and semi - arid regions of the world (Pal et al., 2014), possessing 2n = 16 or 18 number of chromosomes. The varieties Double Flower (ornamental type) and Vellodu consisted of $2 \mathrm{n}=18$ chromosome number. The genus Punica consisted of two species
Punica granatum (cultivated type) and Punica protopunica (wild type). The cultivated pomegranate species Punica granatum possesses two sub - species, viz., Punica granatum ssp. Chlorocarpa and Punica granatum ssp. Porphyrocarpa, which are popularly grown in Mediterranean regions especially Morocco, Spain, Egypt and 
Afghanistan. It is also grown to some extent in countries like Myanmar, China, Japan, USA, Russia, Bulgaria and Southern Italy.

Globally, India is the leader both in area and production of pomegranate. It produces 2.19 MT of pomegranate from an area of $0.19 \mathrm{~m}$ ha (Anonymous, 2016). Among the states, Maharashtra is considered as 'pomegranate basket of India' because of high cultivation area and production followed by Karnataka, Andhra Pradesh and Rajasthan. In past few years, the area under pomegranate cultivation in India is increasing due to its versatile adaptability, hardy nature, drought tolerance, low maintenance cost, high remunerative nature and good keeping quality, besides owing of medicinal properties due to presence of anthocyanins viz., Cyanidin 3, 5 diglucoside, Cyanidin 3 - glucoside, Delphinidin 3, 5- diglucoside, Delphinidin 3 glucoside, Pelargonidin 3, 5 - diglucoside and Pelargonidin 3 - glucoside (Du et al., 1975). Pomegranate is also rich in ellagic acid and punicalgins, which are believed to be potent antioxidants.

The flowering habit of pomegranate is influenced by the prevailing climatic conditions of the geographical region where it is being grown (Pareek and Sharma, 1993). The inflorescence is a dichasial cyme. Flowers can appear solitary, in pairs or in clusters. There are three kinds of flowers borne on the same plant viz., staminate, hermaphrodite and intermediate which occur in about 1 month after bud break on newly developed branches of the same year, mostly on spurs or short branches (Babu et al., 2009). The male flowers are companulate (bell shaped) whereas the hermaphrodite flowers are urcerate (vase - shaped). The intermediate ones are tubular in shape. If fruit set takes place in such flowers, they may drop before reaching maturity, even if some fruits which reach maturity tend to be misshaped. The ovary of the male flower is rudimentary whereas that of intermediate flowers are of the degenerating type. The ovary in bisexual is well developed with a broad base. The fruit set in pomegranate depends upon hermaphrodite flowers (Chaudari and Desai, 1993). In tropical climates, pomegranate flowers almost throughout the year whereas in subtropics, once a year. In temperate regions, during winter, the plant is deciduous, but in tropical conditions, it is evergreen and flower throughout the year (Hayes, 1957). Since the crop behaves as evergreen under tropical climatic conditions of India, it flowers continuously throughout the year resulting lower yield and poor quality fruit due to depletion of plant reserves. Thus, synchronization of flowering is an ideal option for fetching better yield and quality fruits. Plant growth chemicals play an important role in manipulation of flowering and fruiting in many perennial fruit crops like citrus, grapes and mango etc. Thus in the present investigation, we studied the effects of plant growth chemicals like Nitrobenzene, Cycocel and Uracil applied at different concentrations on flowering and fruiting besides physiological parameters in cV Bhagwa during Ambe bahar (January February) season.

\section{Materials and Methods}

The present study was conducted on healthy and uniformly grown tissue culture plants of pomegranate $\mathrm{cv}$ Bhagwa procured from M/S Jain Irrigation Pvt Ltd, Jalgoan (Maharashtra) at ICAR- Indian Institute of Horticultural Research, Hesaraghatta farm, Bengaluru during Ambe bahar (January to February) season of the years 2016-17. ICAR - IIHR is situated at an altitude of 890 meter above mean sea level at $13^{0} 7^{-}$North latitude and $77^{0} 29^{`}$ East longitude respectively. The maximum and minimum temperatures recorded during the experiment were $33.08^{\circ} \mathrm{C}$ 
and $20.43^{\circ} \mathrm{C}$ and relative humidity and rainfall recorded were $75.04 \%$ and $74.95 \mathrm{~mm}$ respectively. The experiment consisted of eleven treatments which were replicated thrice and the statistical design used was Randomized Block Design (RBD). The treatments included were $T_{1}-$ Nitrobenzene (NB)@1.0 ml litre ${ }^{-1}$ plant $^{-1}, \mathrm{~T}_{2}-\mathrm{NB} @ 1.5$ $\mathrm{ml}$ litre $^{-1}$ plant $^{-1}, \mathrm{~T}_{3}-\mathrm{NB} @ 2.0 \mathrm{ml}$ litre $^{-1}$ plant $^{-1}, \mathrm{~T}_{4}$ - Cycocel (CCC) @ 500 ppm litre $\mathrm{pl}^{-1}$ plant $^{-1}, \mathrm{~T}_{5}$ - CCC @ 1000 ppm litre ${ }^{-1}$ plant $^{-1}$, $\mathrm{T}_{6}$ - CCC @ 1500 ppm litre ${ }^{-1}$ plant $^{-1}, \mathrm{~T}_{7}$ Uracil @ 25 ppm litre ${ }^{-1}$ plant $^{-1}, \mathrm{~T}_{8}$ - Uracil @ 50 ppm litre ${ }^{-1}$ plant $^{-1}, \mathrm{~T}_{9}-\mathrm{T} 5+\mathrm{T} 7, \mathrm{~T}_{10}-\mathrm{T} 6$ $+\mathrm{T} 8$ and $\mathrm{T}_{11}-$ Control. Six plants were selected under each treatment. The standard cultural practices such as pruning of twigs, defoliation with ethrel @ $2.0 \mathrm{ml}$ litre $^{-1}$ and desuckering were adopted prior to and during the investigation.

After fifteen days of treatment, observations were recorded on flower types, fruit yield and physiological parameters at flowering and fruit set stages. Number of male, hermaphrodite and intermediate flowers plant ${ }^{-1}$ were recorded by selecting the one quarter of tree canopy and counting of flower number under each quadrant and multiplying the number with four. The fruit set was determined by counting the lemon sized fruits present on entire plant. The individual fruit weight was recorded by randomly selecting nine fruits under each treatment, and the mean value was expressed in $g$ fruit ${ }^{-1}$. The percentage of fruit set was calculated by formula:

Number of fruits harvested

Number of hermaphrodite flowers

At harvest, the number of fruits from all the treatments was counted and the mean value was expressed as number of fruits tree ${ }^{-1}$. Fruit yield was recorded by recording weight of fruits harvested at maturity and expressed as $\mathrm{kg}$ tree $^{-1}$. The gas exchange parameters (photosynthesis rate $\left(P_{N}\right)$, transpiration rate (E) and stomatal conductance $\left(\mathrm{g}_{\mathrm{s}}\right)$ were measured using the Infra-Red Gas Analyser, (LC PRO portable gas exchange system (ADC BioScientific Ltd, Hoddesdon, UK).

Water use efficiency (WUE) was calculated by ratio between $P_{N}$ : E. For all these measurements, young fully expanded leaf (second or third leaf counting from the shoot apex) was selected. Measurements were carried out in the morning $(9.00-11.00$ a.m. $)$ at steady light intensity $\left(>900 \mathrm{~mol} \mathrm{~m}^{-2} \mathrm{~s}^{-1}\right)$. The data was analyzed as per the method of variance outlined by Panse and Sukhatme (1985). Statistical significance was tested by $\mathrm{F}$ value at 5\% level of significance. Critical difference at 0.05 levels was worked out for the effects which were significant.

\section{Results and Discussion}

\section{Number of flowers}

The data presented in table 1 showed that the treatments significantly increased the number of hermaphrodite flowers (264.7) with Uracil @ $50 \mathrm{ppm}$ being relatively more effective. No significant differences were recorded in male and intermediate flowers number by the imposed treatments. The increase in hermaphrodite flower by Uracil might be the effect of Uracil induced increase in RNA content (Ramteke and Somkumar, 2005) as Uracil is an entity of RNA, which plays role in protein synthesis and gene expression, and thereby phytohormone production for better production (Mathur and Sharma, 1968).

\section{Yield and its attributes}

The data presented in table 2 indicated that application of CCC @ 1000 ppm along with Uracil @25 ppm plant $^{-1}\left(\mathrm{~T}_{9}\right)$ realized significantly higher fruit weight (197.55 g) as 
compared to control. The increase in fruit weight with CCC could be attributed to its inhibitory action by exhibiting anti gibberellin response, and possible diversion of photosynthates for flowering and fruiting (Guha, 1993; Mansuroglu et al., 2009). In contrast, maximum number of fruits (154.00), fruit yield $\left(27.10 \mathrm{~kg}\right.$ tree ${ }^{-1}$ and $\left.18.86 \mathrm{t} \mathrm{ha}^{-1}\right)$ were recorded in plants applied with Uracil @
$50 \mathrm{ppm}$ plant $^{-1}\left(\mathrm{~T}_{8}\right)$, which could be the result of observed increase in hermaphrodite flowers under this treatment. Chaudari and Desai (1993) reported positive relationship between the percentage of hermaphrodite flowers and bearing capacity in pomegranate cv Mridula. However, no significant differences were apparent among the treatments with respect to percentage of fruit set.

Table.1 Induction of flowering in pomegranate cv Bhagwa as influenced by different growth chemicals

\begin{tabular}{|c|c|c|c|}
\hline Treatments & $\begin{array}{l}\text { Number of } \\
\text { Male Flowers }\end{array}$ & $\begin{array}{l}\text { Number of } \\
\text { Hermaphrodite Flowers }\end{array}$ & $\begin{array}{l}\text { Number of } \\
\text { Intermediate Flowers }\end{array}$ \\
\hline$T_{1}-$ NB @ 1.0 ml plant ${ }^{-1}$ & 277.83 & 215.66 & 179.66 \\
\hline $\mathrm{T}_{2}-\mathrm{NB} @ 1.5 \mathrm{ml}$ plant $^{-1}$ & 287.66 & 206.66 & 201.83 \\
\hline$T_{3}-$ NB @ 2.0 ml plant ${ }^{-1}$ & 241.00 & 211.66 & 198.66 \\
\hline $\mathbf{T}_{4}-\mathrm{CCC} @ 500$ ppm plant ${ }^{-1}$ & 274.00 & 193.33 & 197.16 \\
\hline$T_{5}-$ CCC @ 1000 ppm plant ${ }^{-1}$ & 264.66 & 196.66 & 195.66 \\
\hline$T_{6}-$ CCC @ 1500 ppm plant ${ }^{-1}$ & 258.00 & 190.66 & 196.66 \\
\hline $\mathbf{T}_{7}$-Uracil @ 25 ppm plant ${ }^{-1}$ & 268.66 & 259.66 & 195.66 \\
\hline $\mathbf{T}_{8}-$ Uracil @ 50 ppm plant ${ }^{-1}$ & 288.33 & 264.66 & 194.33 \\
\hline $\mathbf{T}_{9}-\mathbf{T 5}+\mathbf{T} 7$ & 275.33 & 201.33 & 207.83 \\
\hline$T_{10}-T 6+T 8$ & 258.00 & 196.00 & 226.66 \\
\hline $\mathbf{T}_{11}-$ Control & 312.33 & 188.66 & 190.00 \\
\hline C.D. at $5 \%$ & N.S. & 44.10 & N.S \\
\hline S.Em $( \pm)$ & 16.74 & 14.84 & 12.27 \\
\hline $\mathrm{CV} \%$ & 10.61 & 12.16 & 10.70 \\
\hline
\end{tabular}

$* \mathrm{NB}-$ Nitrobenzene and CCC - Cycocel

Table.2 Effect of different chemicals on fruit yield and its attributes in pomegranate cv Bhagwa

\begin{tabular}{|c|c|c|c|c|c|}
\hline Treatments & $\begin{array}{l}\text { Fruit } \\
\text { weight (g) }\end{array}$ & $\begin{array}{l}\text { Percentage } \\
\text { of fruit set }\end{array}$ & $\begin{array}{l}\text { Number of } \\
\text { fruits plant }^{-1}\end{array}$ & $\begin{array}{c}\text { Fruit yield } \\
\left(\text { kg tree }^{-1}\right)\end{array}$ & $\begin{array}{l}\text { Fruit yield } \\
\left(t^{-1} \mathbf{a}^{-1}\right)\end{array}$ \\
\hline$T_{1}-$ NB @ 1.0 ml plant $^{-1}$ & 177.80 & 66.30 & 139.16 & 24.73 & 8.51 \\
\hline$T_{2}-\mathrm{NB} @ 1.5 \mathrm{ml} \mathrm{plant}^{-1}$ & 187.07 & 55.76 & 113.83 & 21.50 & 9.89 \\
\hline$T_{3}-$ NB @ 2.0 ml plant $^{-1}$ & 183.00 & 62.77 & 132.00 & 24.18 & 9.66 \\
\hline$T_{4}-$ CCC @ 500 ppm plant ${ }^{-1}$ & 196.31 & 51.67 & 99.66 & 19.61 & 7.82 \\
\hline$T_{5}-$ CCC @ 1000 ppm plant ${ }^{-1}$ & 193.66 & 54.22 & 105.00 & 20.36 & 8.13 \\
\hline$T_{6}-$ CCC @ 1500 ppm plant ${ }^{-1}$ & 187.25 & 52.01 & 99.16 & 18.70 & 7.42 \\
\hline $\mathbf{T}_{7}-$ Uracil @ 25 ppm plant ${ }^{-1}$ & 176.82 & 59.09 & 153.00 & 26.98 & 10.82 \\
\hline $\mathbf{T}_{8}-$ Uracil @ 50 ppm plant ${ }^{-1}$ & 176.88 & 58.16 & 154.00 & 27.10 & 18.86 \\
\hline $\mathbf{T}_{9}-\mathrm{T} 5+\mathbf{T} 7$ & 197.55 & 55.55 & 107.00 & 20.98 & 8.45 \\
\hline$T_{10}-T 6+T 8$ & 187.43 & 56.08 & 106.00 & 19.84 & 7.94 \\
\hline$T_{11}-$ Control & 166.54 & 52.05 & 98.33 & 16.31 & 6.65 \\
\hline C.D. at 5\% & 15.66 & N.S. & 31.90 & 6.39 & -- \\
\hline S.Em ( \pm$)$ & 5.27 & 7.00 & 10.73 & 2.15 & -- \\
\hline CV \% & 4.94 & 21.40 & 15.65 & 17.05 & -- \\
\hline
\end{tabular}

*NB - Nitrobenzene and CCC - Cycocel 
Table.3 Gas Exchange parameters in pomegranate cv Bhagwa as influenced by different chemicals during flowering and fruit set stages

\begin{tabular}{|c|c|c|c|c|c|c|}
\hline & \multicolumn{3}{|c|}{ Flowering stage } & \multicolumn{3}{|c|}{ Fruit set stage } \\
\hline Treatments & $\begin{array}{c}\text { Photosynthesis (P } \\
N) \\
\left(\mu \mathrm{mol} \mathrm{m} \mathbf{m}^{-2} \mathrm{~s}^{-1}\right)\end{array}$ & $\begin{array}{c}\text { Transpiration } \\
(\mathbf{E}) \\
\left(\mathbf{m m o l ~ \mathbf { ~ } ^ { - 2 }} \mathbf{s}^{-1}\right)\end{array}$ & $\begin{array}{c}\text { Stomatal } \\
\text { conductance } \\
\left(\mathrm{g}_{\mathrm{s}}\right) \\
\left(\mathrm{mol} \mathrm{m}^{-2} \mathrm{~s}^{-1}\right)\end{array}$ & $\begin{array}{c}\text { Photosynthesis } \\
\left(\boldsymbol{P}_{N}\right) \\
\left(\mu \mathrm{mol} \mathrm{\mathbf {m } ^ { - 2 }} \mathbf{s}^{-1}\right)\end{array}$ & $\begin{array}{c}\text { Transpiration } \\
(\mathbf{E}) \\
\left(\mathbf{m m o l ~ \mathbf { ~ } ^ { - 2 }} \mathbf{s}^{-1}\right)\end{array}$ & $\begin{array}{c}\text { Stomatal } \\
\text { conductance } \\
\left(\mathrm{g}_{\mathrm{s}}\right) \\
\left(\mathrm{mol} \mathrm{m}^{-2} \mathbf{s}^{-1}\right) \\
\end{array}$ \\
\hline $\begin{array}{l}\text { T1 - NB @ } \\
1.0 \text { ml plant }{ }^{-1}\end{array}$ & 15.22 & 3.49 & 0.43 & 9.80 & 4.45 & 0.19 \\
\hline $\begin{array}{l}\text { T2 - NB @ } \\
1.5 \text { ml plant }^{-1}\end{array}$ & 13.41 & 4.92 & 0.44 & 12.55 & 4.83 & 0.14 \\
\hline $\begin{array}{l}\text { T3-NB @ } \\
2.0 \text { ml plant }^{-1}\end{array}$ & 11.63 & 5.07 & 0.38 & 9.48 & 4.94 & 0.16 \\
\hline $\begin{array}{l}\text { T4-CCC @ } \\
500 \text { ppm plant }\end{array}$ & 14.65 & 4.21 & 0.23 & 10.63 & 5.32 & 0.14 \\
\hline $\begin{array}{l}\text { T5 - CCC @ } \\
1000 \text { ppm plant }\end{array}$ & 14.12 & 5.56 & 0.31 & 11.71 & 5.73 & 0.16 \\
\hline $\begin{array}{l}\text { T6-CCC @ } \\
1500 \text { ppm plant }\end{array}$ & 13.28 & 6.53 & 0.31 & 10.87 & 5.08 & 0.13 \\
\hline $\begin{array}{l}\text { T7 - Uracil @ } \\
25 \text { ppm plant }\end{array}$ & 15.22 & 7.72 & 0.31 & 10.67 & 3.44 & 0.14 \\
\hline $\begin{array}{l}\text { T8-Uracil @ } \\
50 \text { ppm plant }\end{array}$ & 16.48 & 7.03 & 0.26 & 9.55 & 3.85 & 0.15 \\
\hline $\mathrm{T} 9-\mathrm{T} 5+\mathrm{T} 7$ & 11.53 & 7.03 & 0.21 & 11.88 & 6.19 & 0.18 \\
\hline $\mathrm{T} 10-\mathrm{T} 6+\mathrm{T} 8$ & 13.84 & 7.69 & 0.24 & 10.26 & 4.58 & 0.13 \\
\hline T11 - Control & 10.47 & 2.37 & 0.09 & 9.00 & 3.48 & 0.13 \\
\hline CD@ $9 \%$ & 4.21 & 1.74 & 0.16 & 3.24 & 1.89 & 0.07 \\
\hline CV \% & 18.17 & 18.32 & 32.66 & 17.98 & 23.51 & 28.01 \\
\hline S.Em ( \pm$)$ & 1.42 & 0.59 & 0.05 & 1.09 & 0.64 & 0.02 \\
\hline
\end{tabular}

$* \mathrm{NB}-$ Nitrobenzene and CCC - Cycocel

Table.4 Influence of different chemicals on intrinsic water use efficiency in pomegranate cv Bhagwa

\begin{tabular}{|c|c|c|}
\hline & Flowering stage & Fruit set stage \\
\hline$T_{1}-$ NB @ 1.0 ml plant ${ }^{-1}$ & 4.34 & 2.45 \\
\hline$T_{2}-$ NB @ 1.5 ml plant ${ }^{-1}$ & 2.80 & 2.62 \\
\hline$T_{3}-$ NB @ 2.0 ml plant ${ }^{-1}$ & 2.30 & 1.88 \\
\hline$T_{4}-$ CCC @ 500 ppm plant ${ }^{-1}$ & 3.81 & 2.00 \\
\hline$T_{5}-$ CCC @ 1000 ppm plant ${ }^{-1}$ & 2.54 & 2.04 \\
\hline$T_{6}-$ CCC @ 1500 ppm plant ${ }^{-1}$ & 2.06 & 2.14 \\
\hline $\mathbf{T}_{7}$-Uracil @ 25 ppm plant ${ }^{-1}$ & 1.98 & 3.09 \\
\hline $\mathbf{T}_{8}-$ Uracil @ 50 ppm plant ${ }^{-1}$ & 2.40 & 2.53 \\
\hline $\mathbf{T}_{9}-\mathbf{T} 5+\mathbf{T} 7$ & 4.52 & 1.93 \\
\hline$T_{10}-T 6+T 8$ & 1.79 & 2.29 \\
\hline $\mathbf{T}_{11}-$ Control & 1.65 & 2.66 \\
\hline C.D. at 5\% & 1.135 & N.S. \\
\hline S.Em ( \pm$)$ & 0.382 & 0.274 \\
\hline $\mathrm{CV} \%$ & 24.088 & 20.362 \\
\hline
\end{tabular}

*NB - Nitrobenzene and CCC - Cycocel 


\section{Gas exchange characteristics}

All the treatments were significantly influenced the gas exchange parameters both at flowering and fruiting stages. At flowering stage, higher photosynthetic rate $(16.48 \mu \mathrm{mol}$ $\left.\mathrm{m}^{-2} \mathrm{~s}^{-1}\right)$ was registered with the application of Uracil @ 50 ppm plant ${ }^{-1}\left(\mathrm{~T}_{8}\right)$ while its 25 ppm plant $^{-1}\left(\mathrm{~T}_{7}\right)$ treatment registered higher transpiration rate $\left(7.72 \mathrm{mmol} \mathrm{m}^{-2} \mathrm{~s}^{-1}\right)$. The stomatal conductance $\left(0.44 \mathrm{~mol} \mathrm{~m}^{-2} \mathrm{~s}^{-1}\right)$ was high in plants applied with Nitrobenzene @ $1.5 \mathrm{ml} \mathrm{plant}^{-1}$. There was reduction in gas exchange parameters at fruit set stage compared to flowering stage, which could be attributed to the higher demand for photosynthates for the onset of flowering as reported by Monselise and Lenz (1980). In further support to this Masarovicova and Novara (1994) reported in Apple, higher photosynthesis rate in leaves adjacent to developing flowers as compared to those adjacent to vegetative shoots (Table 3 ).

\section{Intrinsic Water use Efficiency (WUE)}

Water use efficiency (WUE) was significantly increased under $T_{9}$ followed by $T_{1}$ at flowering stage as compared to fruiting stage. The higher WUE is attributed to greater increase in photosynthetic rate over transpiration rate which is required for the initiation of flowering. Higher WUE helps plants in achieving better flowering, as water availability is crucial for its onset and further development (Table 4).

\section{Acknowledgement}

I would like to thank Dr K K Upreti, Principal Scientist, Division of Plant Physiology and Bio chemistry, ICAR - IIHR for his critical review of paper and remarks. Concurrently, I also thank Dr R.H. Laxman, Principal Scientist, Division of Plant Physiology and Biochemistry, ICAR - IIHR for his continuous support and guidance throughout the investigation.

\section{References}

Anonymous, 2016. $2^{\text {nd }}$ Advance Estimate. National Horticulture Board. Pp - 6 .

Babu, K.D., Chandra R., Jadhav, V.T and Sharma, J. 2009. Blossom biology of pomegranate cv. Bhagwa under semiarid tropics of western India. Abstracts of $2^{\text {nd }}$ International Symposium on Pomegranate and Minor Including Mediterranean Fruits, June 23-27, 2009, University of Agricultural Sciences, Dharwad, India, pp 88-89.

Chaudari, S.M., and Desai, U.T. 1993. Effects of plant growth regulators on flower sex in pomegranate (Punica granatum). Indian Journal of Agricultural Sciences. 63: 34-35.

Du, T., Wang, P.C and Francis, F.J. 1975. Anthocyanins of pomegranate. J. Sci. 40: 417-418.

Ferree, D.C., and Palmer, J, W. 1992. Effect of spur defoliation and ringing during bloom on fruiting, fruit mineral level and net photosynthesis of Golden Delicious apple. J. Amer. Soc. Hort. Sci. 107: 1182-1186.

Guha, D., 1993. Regulation of tree growth and yield in Golden Delicious apple with Cycocel and ethrel. South Indian J. Hort., 41(6): 333-340.

Hayes, W.B., 1957. Fruit Growing in India. $3^{\text {rd }}$ Edn, Kitabistan, Allahabad, pp. 502.

Mansuroglu, S., Karaguzel, O, Ortacesme, V and Sayan, M.S. 2009. Effect of Paclobutrazol on flowering, leaf and flower colour of Consolida orientalis. Pakistan J. Bot. 41: 2323-2332.

Masarovicova, E., and Novara, J. 1994. Influence of fruit load on $\mathrm{CO}_{2}$ exchange, water uptake and biomass of apple trees. Gartenbauwissenchaft. 59: 132-138. 
Mathur, S.N., and Sharma, R.A. 1968. Effect of Uracil and 5 - Nitrouracil on Growth and Flowering of Tomato. Physiologia Plantarum. 21: 911-917.

Monselise, S.R., and Lenz, F. 1980. Effect of fruit load on photosynthetic rates of budded apple trees. Gartenbauwissenchaft. 45: 220-224.

Pal, R.K., Dhinesh Babu, K., Singh, N.V., Ashish Maity and Nilesh Gaikwad. 2014. Pomegranate Research in India Status and future challenges. Progressive Horticulture. 46(2):184-20.
Panse, V. S., and Sukhatme, P.V. 1985. Statistical Methods for Agricultural Workers, ICAR, New Delhi.

Pareek, O.P., and Sharma, S. 1993. Genetic resources of under exploited fruits. In: Chadha KL, Pareek, OP (Eds) Advances in Horticulture (Vol1), Malhotra Publication, New Delhi, pp 189-225.

Ramteke, S.D., and Somkumar, R.G. 2005. Effect of quantum on increasing growth, yield and quality of grapes. Karnataka J. Agric Sci. 18(1): 13-17.

\section{How to cite this article:}

Firoz Hussain, S., P. Sampath Kumar, B.N.S. Murthy, K.K. Upreti, M.L.N. Reddy, J. Satisha and Laxman, R.H. 2017. Use of Chemicals to Realize the Productivity Potential in Pomegranate through Increased Flowering and Fruiting. Int.J.Curr.Microbiol.App.Sci. 6(10): 1937-1943. doi: https://doi.org/10.20546/ijcmas.2017.610.233 